\title{
STUDY RESPON INVESTOR TERHADAP OPINI GOING CONCERN
}

\author{
Aji Prasetyo \\ Institut Ilmu Sosial dan Manajemen Stiami \\ aji.prasetyo32@gmail.com
}

\begin{abstract}
Abstrak. Ini adalah laporan bursa saham. Bursa Efek (BEI) pada tahun 2012-2013 sehingga jumlah sampel $(n)=106$. Penentuan sampel dengan metode sampling, sampel dipilih dengan kriteria yang ditentukan.

Sampel data dikumpulkan dengan menggunakan studi literatur dan dokumentasi. Data yang terkumpul akan dianalisis dengan analisis statistik deskriptif, Uji beda dan asumsi klasik. Analisis statistik deskriptif dilakukan untuk mengetahui penyebaran dan distribusi data. Tes yang berbeda digunakan untuk menguji hipotesis. Sedangkan uji asumsi klasik dilakukan untuk menguji kelayakan model regresi linier berganda yang kemudian digunakan untuk menguji hipotesis penelitian.

Dalam penelitian ini ditemukan bukti bahwa tidak ada perbedaan antara abnormal return dan pendapat opini going concern terhadap return abnormal kumulatif.
\end{abstract}

Kata kunci: going concern opinion, opini wajar tanpa pengecualian, return abnormal kumulatif

Abstract. This research aims to analyze the response of investors to the going concern opinion on issuers listed on the Indonesia Stock Exchange.

The population used in this research are all companies listed on the Indonesia Stock Exchange (IDX) in 2012-2013 so that the number of samples $(n)=106$. Determination of sample do with purposive sampling method, samples are selected using criteria specified.

Samples of data are collected using literature study and documentation. The data collected will be analyzed with descriptive statistical analysis, Different test and classical assumption. Descriptive statistical analysis was conducted to determine the dispersion and distribution of data. Different test is used to test the differences between the two variables are then used to test the research hypotheses. While the classical assumption test was conducted to test the feasibility of multiple linear regression models were then used to test the research hypotheses.

In this research found evidence that there is no difference between the abnormal returns before going concern opinion issued by after receiving going concern opinion, there is no difference between the abnormal return issuers obtain going concern opinion with which to obtain an unqualified opinion and no significant influence going concern opinion to the cumulative abnormal return.

Keywords :going concern opinion, unqualified opinion, cummulative abnormal return

\section{PENDAHULUAN}

Krisis keuangan Amerika Serikat yang terjadi pada akhir tahun 2008 adalah krisis keuangan terparah sejak perang dunia kedua. Semuanya berawal dari kasus subprime mortgage yang sempat menjadi instrumen investasi primadona di Amerika Serikat. Subprime mortgage adalah fasilitas kredit perumahan dengan syarat ringan namun dengan bunga yang tinggi dengan target masyarakat golongan menengah ke bawah di Amerika Serikat. Krisis ini menyebabkan kebangkrutan perusahaan raksasa New Century Financial Corporation dan Lehman Brothers (Purba, 2009:4-5).

Dampak dari krisis keuangan Amerika Serikat juga berimbas terhadap Indonesia, dalam Outlook Ekonomi Indonesia: Krisis Finansial Global dan Dampaknya terhadap 
Perekonomian Indonesia, oleh Biro Riset Ekonomi Direktorat Riset Ekonomi dan Kebijakan Moneter, Bank Indonesia (2009) menyatakan krisis kredit macet perumahan berisiko tinggi (subprime mortgage) di Amerika Serikat secara tiba-tiba berkembang menjadi krisis keuangan global, dan kemudian dalam hitungan bulan telah berubah menjadi krisis ekonomi yang melanda ke seluruh dunia. Banyak ahli tidak menyangka krisis keuangan di Amerika Serikat yang terjadi pada tahun 2008 akan berimplikasi secara global dan mengakibatkan kepailitan besar-besaran. Krisis keuangan global tersebut berdampak terhadap kemampuan Perusahaan dalam kelangsungan hidupnya. Besar dampaknya disetiap negara bisa bervariasi, tergantung sejauh mana negara tersebut memiliki ketergantungan terhadap pasar global.

Di sisi lain, banyak para peneliti yang meneliti dampak dari timbulnya krisis yang ada pada paragraph sebelumnya, salah satunya yaitu pemberian opini audit going concern. Dari beberapa peneliti yang meneliti dampak tersebut menyatakan bahwa pemberian opini audit going concern mempunyai pengaruh yang signifikan terhadap prediksi kebangkrutan dan dapat membantu para investor dalam mengambil reaksi dan sikap didalam investasinya.

Melihat fenomena yang ada dari hasil penelitian diatas ternyata terdapat juga fakta yang terjadi, yang menyatakan bahwa tidak semua Investor mengambil reaksi akibat pemberiaan opini audit going concern, karena beberapa investor menganggap bahwa opini audit going concern maupun opini unqualified memberikan informasi yang sama, hal tersebut di buktikan oleh Richard J. Taffler dan Christine E.L.Tan (2006) yang meneliti perusahaan di inggris karena menurutnya opini audit going concern tidak berisi informasi baru yang ada di pasar Modal.

Di Indonesia sendiri, terdapat beberapa perusahaan pada tahun 2011 yang mendapatkan opini going concern tetapi masih tetap stabil harga sahamnya di pasar modal, seperti PT Star Pasific Tbk, Pembangunan Graha Lestari Indah Tbk, PT
Hanson International Tbk. sehingga atas kejadian tersebut peneliti beranggapan bahwa investor memberikan respon yang sama atas opini audit going concern dengan opini unqualified.

Going concern adalah kelangsungan hidup suatu badan usaha dan merupakan asumsi dalam pelaporan keuangan suatu entitas sehingga jika suatu entitas mengalami kondisi yang sebaliknya, entitas tersebut menjadi bermasalah (Petronela, 2004). Asumsi going concern berarti suatu badan usaha dianggap akan mampu mempertahankan kegiatan usahanya dalam jangka waktu panjang dan tidak akan dilikuidasi dalam waktu jangka pendek (Hani et al, 2003).

Menurut Susanto (2009), masalah going concern suatu perusahaan merupakan hal yang sangat penting untuk diketahui dan diungkapkan, agar perusahaan dapat mengambil tindakan selanjutnya dan pertimbangan keputusan yang tepat untuk mempertahankan kelangsungan hidup usahanya sehingga terhindar dari kebangkrutan.

Dengan demikian, auditor mempunyai peranan penting dalam menjembatani antara kepentingan investor sebagai pengguna laporan keuangan dan kepentingan perusahaan sebagai penyedia laporan keuangan. Data perusahaan akan lebih mudah dipercaya oleh investor dan pemakai laporan keuangan lainnya apabila laporan keuangan tersebut mencerminkan kinerja dan kondisi perusahaan dan telah mendapat pernyataan wajar dari auditor. Pernyataan auditor diungkapkan melalui opini audit. Dengan menggunakan laporan keuangan yang telah diaudit, para pemakai laporan keuangan dapat mengambil keputusan dengan benar sesuai dengan kenyataan yang sesungguhnya (Susanto, 2009).

Studi sebelumnya (Chen dan Church, 1996) menunjukkan adanya nilai informasi dalam opini going concern, bahwa opini going concern berguna untuk menjelaskan reaksi pasar terhadap kebangkrutan perusahaan. Firth dalam liany leo (2007) menemukan bahwa beberapa jenis kualifikasi audit memiliki dampak signifikan terhadap 
keputusan investasi. Liany leo (2007) menemukan bahwa ketakutan adanya paragraf penjelasan akan menurunkan harga saham sebagai reaksi negatif pasar tidak terbukti dalam penelitian ini. Sebaliknya, penelitian ini mendapatkan bukti empiris bahwa pasar memberikan respon positif terhadap paragraf penjelasan dalam opini unqualified.

Mengikuti pengujian asosiasi opini audit terhadap reaksi pasar, Chen dan Church (1996), Firth (1978) dan liany leo (2007) menguji apakah return saham perusahaan yang mendapatkan opini audit unqualified dengan penekanan atas suatu hal (dengan paragraf penjelasan) sama dengan return saham perusahaan yang mendapatkan opini audit unqualified.

Studi ini fokus pada membandingkan reaksi pasar terhadap opini going concern dengan unqualified, yang dapat disebabkan oleh penyimpangan dari prinsip akuntansi yang tidak material, perubahan prinsip atau metode akuntansi yang berakibat material terhadap daya banding laporan keuangan, dan atau penekanan atas suatu hal.

\section{KAJIAN PUSTAKA, RERANGKA PEMIKIRAN, DAN HIPOTESIS}

\section{Kajian Pustaka}

\section{Teori Keagenan}

Jensen dan Meckling (1976) mendefinisikan hubungan keagenan sebagai suatu perjanjian dimana satu orang atau lebih (prinsipal) meminta pihak lainnya (agen) untuk melaksanakan sejumlah pekerjaan atas nama prinsipal yang melibatkan pendelegasian beberapa wewenang pembuatan keputusan kepada agen. Jika kedua pihak yang terlibat dalam kontrak tersebut berusaha untuk memaksimalkan kepentingan mereka maka ada kemungkinan bahwa agen tidak akan selalu bertindak untuk kepentingan terbaik prinsipal. Prinsipal dapat membatasi penyimpangan agen dengan melakukan monitoring terhadap agen akan tetapi hal ini membutuhkan biaya tambahan yang besar bagi prinsipal. Dalam situasi tertentu prinsipal dapat memberikan insentif tambahan kepada agen untuk memperoleh jaminan bahwa agen akan bertindak untuk kepentingan prinsipal dan tidak bertindak yang dapat merugikan prinsipal.

Messier, Glover dan Prawitt (2006:8-

10) menjelaskan peran auditor dalam hubungan prinsipal dan agen sebagai berikut:

1) Hubungan antara prinsipal (pemilik) dan agen (manajer) sering berakhir dengan informasi yang asymetris antara kedua belah pihak. Informasi asimetris terjadi karena manajer secara umum memiliki lebih banyak informasi mengenai posisi keuangan "yang sebenarnya" dan hasil operasi entitas daripada pemilik yang tidak di tempat (absente owner).

2) Tujuan antara pemilik dan manajer mungkin tidak sama, akan terdapat konflik kepentingan (conflict of interest) yang alami antara manajer dan pemilik yang tidak hadir. Sehingga apabila kedua pihak berusaha untuk memaksimumkan kepentingan mereka sendiri maka manajer tidak akan selalu bertindak sesuai dengan kepentingan pemilik.

Oleh sebab itu, audit memainkan peran yang penting dalam memonitor hubungan kontrak antara entitas dan pemegang saham, manajer, pegawai, dan pemberi utang. Auditor independen diminta untuk menyediakan jasa audit karena reputasi tradisional mereka dalam hal kompetensi, independensi, objektivitas, dan pertimbangan mengenai kepentingan publik.

\section{Teori Pasar Modal Efisien}

Pasar modal yang efisien didefinisikan sebagai pasar modal yang harga sekuritassekuritasnya mencerminkan semua informasi yang relevan. Fama (1970) mengklasifikasikan informasi menjadi tiga tipe, yaitu

1. Past price changes (perubahan harga diwaktu yang lalu),

2. Informasi yang tersedia kepada publik (public information), dan 
3. Informasi yang tersedia baik kepada publik maupun tidak (public and private information).

\section{Teori Signaling}

Signalling theory menekankan kepada pentingnya informasi yang dikeluarkan oleh perusahaan terhadap keputusan investasi pihak di luar perusahaan. Informasi merupakan unsur penting bagi investor dan pelaku bisnis karena informasi pada hakekatnya menyajikan keterangan, catatan atau gambaran baik untuk keadaan masa lalu, saat ini maupun keadaan masa yang akan datang bagi kelangsungan hidup suatu perusahaan dan bagaimana pasaran efeknya. Informasi yang lengkap, relevan, akurat dan tepat waktu sangat diperlukan oleh investor di pasar modal sebagai alat analisis untuk mengambil keputusan investasi.

Menurut Jogiyanto (2000), informasi yang dipublikasikan sebagai suatu pengumuman akan memberikan signal bagi investor dalam pengambilan keputusan investasi. Jika pengumuman tersebut mengandung nilai positif, maka diharapkan pasar akan bereaksi pada waktu pengumuman tersebut diterima oleh pasar. Pada waktu informasi diumumkan dan semua pelaku pasar sudahmenerima informasi tersebut, pelaku pasar terlebih dahulu menginterpretasikan dan menganalisis informasi tersebut sebagai signal baik (good news) atau signal buruk (bad news).

\section{Opini Audit Going Concern}

Auditor yang melakukan audit harus selalu mempertimbangkan going concern sekalipun tujuan audit bukan untuk mengevaluasi kesehatan keuangan perusahaan, auditor memiliki tanggung jawab menurut Standar Profesional Akuntan Publik (SPAP) SA Seksi 341 untuk mengevaluasi apakah terdapat kesangsian besar terhadap kemampuan entitas dalam mempertahankan kelangsungan hidup usahanya dalam periode waktu pantas, tidak lebih dari satu tahun sejak tanggal laporan keuangan yang sedang diaudit. Evaluasi auditor berdasarkan atas pengetahuan tentang kondisi dan peristiwa yang ada pada atau yang telah terjadi sebelum pekerjaan lapangan selesai.

Going concern suatu entitas dipengaruhi oleh banyak faktor, diantaranya faktor yang bersifat internal maupun eksternal. Faktor eksternal seperti kondisi pasar, kondisi ekonomi, sosial politik, dan lainnya. Faktor internal perusahaan seperti masalah keuangan, sumber daya manusia, teknologi dan lainnya.

Standar Profesional Akuntan Publik SA Seksi 341 memberikan pedoman pada auditor tentang dampak kemampuan satuan usaha dalam mempertahankan kelangsungan hidup usahanya terhadap opini auditor. Auditor harus mengevaluasi apakah terdapat keraguan besar mengenai kemampuan entitas dalam mempertahankan kelangsungan hidupnya dalam jangka waktu pantas dengan cara sebagai berikut:

1) Auditor akan mempertimbangkan apakah hasil prosedur yang telah dilaksanakan dalam hal perencanaan, pengumpulan bukti audit dan penyelesaian audit dapat mengidentifikasikan keadaan yang menunjukkan adanya kesangsian besar mengenai kemampuan entitas dalam mempertahankan kelangsungan hidupnya dalam jangka waktu yang pantas.

2) Jika auditor yakin bahwa terdapat kesangsian mengenai kemampuan satuan usaha dalam mempertahankan kelangsungan hidupnya dalam jangka waktu pantas, maka auditor tersebut harus:

(i) Memperoleh informasi mengenai rencana manajemen yang ditunjukan untuk mengurangi dampak kondisi dan peristiwa tersebut.

(ii) Menetapkan kemungkinan bahwa rencana tersebut secara efektif dilaksanakan.

3) Setelah auditor mengevaluasi rencana manajemen, ia mengambil kesimpulan apakah ia masih memiliki kesangsian besar mengenai kemampuan entitas dalam mempertahankan kelangsungan hidupnya dalam jangka waktu yang pantas.

\section{Return Saham}


Horne dan Wachoviz (2008) mendefinisikan return sebagai: "Return as benefit which related with owner that includes cash dividend last year which is paid, together with market cost appreciation or capital gain which is realization in the end of the year".

Jenis Return Menurut Jogiyanto (2003) saham dibedakan menjadi dua:

1. Return realisasi merupakan return yang telah terjadi,

2. Return ekspektasi merupakan return yang diharapkan akan diperoleh oleh investor di masa yang akan datang.

Berdasarkan pengertian return, bahwa return suatu saham adalah hasil yang diperoleh dari investasi dengan cara menghitung selisih harga saham periode berjalan dengan periode sebelumnya dengan mengabaikan dividen.

Kelebihan dari return yang sesungguhnya terjadi terhadap return yang diharapkan oleh investor (expected return) dinamakan dengan abnormal return (Jogiyanto,2009). Jenis-jenis abnormal return dapat diklasifikasikan menjadi 4 kelompok:

\section{a. Abnormal return}

Terjadi setiap hari pada setiap jenis saham, yaitu selisih actual return dengan expected return.

b. Average Abnormal Return

Merupakan rerata abnormal return dari semua jenis saham yang sedang dianalisis.

c. Cummulative Abnormal Return

Merupakan kumulatif harian abnormal return dari hari pertama sampai dengan hari berikutnya untuk setiap jenis saham.

d. Cummulative Average Abnormal Return

Merupakan kumulatif harian dari average abnormal return mulai dari hari pertama sampai dengan hari-hari berikutnya.

\section{Profitabilitas}

Menurut Brigham, Houston et al (2009), rasio profitabilitas merupakan sekelompok rasio yang menunjukkan efek gabungan dari likuiditas, manajemen aset, dan utang pada hasil operasi. Rasio ini mencerminkan hasil bersih dari semua kebijakan pembiayaan dan Keputusan operasi. Sedangkan Gitman (2009) menyatakan rasio profitabilitas memungkinkan analis untuk mengevaluasi laba perusahaan sehubungan dengan tingkat penjualan, penggunaan aset atau investasi dari pemegang saham. Tanpa laba, perusahaan tidak dapat menarik modal dari luar.

Sedangkan menurut Sutojo (2000), profitabilitas merupakan ukuran keberhasilan operasi bisnis, apabila dari masa ke masa perusahaan dapat menghasilkan keuntungan yang memadai. Dengan tingkat keuntungan yang memadaai manajemen perusahaan dapat meningkatkan kepercayaan para pemilik serta para investor yang berminat membeli saham baru.

\section{Market to Book Value}

Dalam menggambarkan kondisi keuangan perusahaan, peneliti menggunakan rasio market to book value of equity. Rasio market to book value of equity merupakan proksi berdasarkan harga. Proksi ini menggambarkan permodalan suatu perusahaan. Rasio ini dapat diperoleh dengan mengalikan jumlah lembar saham beredar dengan harga penutupan saham terhadap total ekuitas. Bagi para investor yang akan melakukan pembelian saham perusahaan, penilaian terhadap kemampuan perusahaan dalam mendapatkan dan mengelola modal merupakan suatu hal yang penting. Apabila suatu perusahaan dapat memanfaatkan modalnya dengan baik dalam menjalankan usaha, maka semakin besar kemungkinan harga saham perusahaan tersebut diperkirakan meningkat, return saham pun meningkat. Pemilihan proksi ini mengacu pada Dadri (2011).

\section{Ukuran Perusahaan}

Perusahaan besar dapat memiliki masalah keagenan yang lebih besar (karena lebih sulit untuk dimonitor) sehingga membutuhkan corporate governance yang lebih baik. Di sisi lain, perusahaan kecil bisa 
memiliki kesempatan tumbuh yang tinggi, sehingga membutuhkan dana eksternal, dan seperti argument diatas, membutuhkan mekanisme corporate governance yang baik Diah Kusuma Wardani (2008).

Sesuai teori agensi, dimana perusahaan besar yang memiliki biaya keagenan yang lebih besar akan mengungkapkan informasi yang lebih luas untuk mengurangi biaya keagenan tersebut. Di samping itu, perusahaan besar merupakan emiten yang banyak disoroti, pengungkapan yang lebih besar merupakan wujud tanggung jawab sosial perusahaan (Sembiring, 2005).

\section{RERANGKA PEMIKIRAN}

Terjadinya krisis yang melanda sebuah Negara mengakibatkan beberapa perusahaan bermasalah didalam mempertahankan kelangsungan usahanya. Dengan adanya auditor independen diharapkan mampu memprediksi kelangsungan usaha perusahaan akibat dampak dari adanya krisis yang melanda, sehingga dapat membantu investor dalam menanamkan atau mempertahankan modal yang akan maupun telah mereka investasikan. Untuk mencapai tujuan tersebut diadakan penelitian untuk meneliti respon investor terhadap opini. Didalam penelitian saya, saya menggunakan variable kontrol market to book value, ukuran perusahaan, dan profitabilitas.

\section{Hipotesis}

Ketika kondisi ekonomi berada dalam situasi ketidakpastian yang tinggi, para investor mengharapkan auditor memberikan early warning akan kegagalan keuangan perusahaan (Chen dan Church, 1996). Opini audit atas laporan keuangan menjadi salah satu pertimbangan yang penting bagi investor dalam mengambil keputusan untuk berinvestasi. Oleh karena itu, auditor sangat diandalkan dalam memberikan informasi yang baik bagi investor.

Penelitian yang dilakukan (Chen dan Church, 1996) menunjukkan adanya nilai informasi dalam opini going concern, bahwa opini going concern berguna untuk menjelaskan reaksi pasar terhadap kebangkrutan perusahaan.

Liany leo (2007) menemukan bahwa ketakutan adanya paragraf penjelasan akan menurunkan harga saham sebagai reaksi negatif pasar tidak terbukti dalam penelitian ini. Sebaliknya, penelitian ini mendapatkan bukti empiris bahwa pasar memberikan respon positif terhadap paragraf penjelasan dalam opini unqualified.

Firth (1978) menemukan bahwa kualifikasi atas opini audit diinterpretasikan sebagai bad news sehingga publikasi opini berasosiasi negative dengan harga saham, namun dalam temuannya juga menunjukkan bahwa kualifikasi atas opini audit tidak berdampak pada harga saham. Opini going concern yang dibuat untuk menjelaskan kadaan yang terjadi dalam suatu perusahaan tidak dimaksudkan juga untuk menurunkan kualitas opini unqualified

Berdasarkan uraian tersebut di atas, maka hipotesis yang diajukan adalah sebagai berikut:

Ha1 : Abnormal returns sebelum mendapatkan opini going concern berbeda dengan Abnormal returns setelah mendapatkan opini going concern.

Ha2 : Abnormal returns opini unqualified yang berbeda dengan Abnormal returns opini going concern.

Ha3 : Opini going concern secara signifikan berpengaruh terhadap cumulative abnormal return.

\section{METODE PENELITIAN}

Populasi yang digunakan dalam penelitian ini adalah seluruh perusahaan yang terdaftar pada Bursa Efek Indonesia (BEI) pada tahun 2012-2013.

Penentuan sampel perusahaan dilakukan dengan metode purposive sampling. Dimana dalam penelitian ini, pemilihan anggota sampel penelitian didasarkan pada kriteria sebagai berikut:

1. Perusahaan yang terdaftar di BEI tahun 2012-2013. 
2. Laporan keuangan yang telah diaudit untuk periode yang berakhir 31 Desember tahun 2012-2013 dan telah di laporkan di BEI.

3. Harga saham dan IHSG tersedia di situs web BEI

4. Data-data mengenai variabel penelitian yang akan diteliti tersedia lengkap dalam laporan keuangan tahunan perusahaan yang diterbitkan pada tahun 2012-2013.

Berdasarkan kriteria tersebut diambil sampel sebanya 106 perusahaan yang mewakili tahun 2012-2013 yang terdiri dari 53 perusahaan yang mendapatkan opini going concern dan 53 perusahaan yang mendapatkan opini unqualified.

\section{PEMBAHASAN}

\section{Pengujian Univariate}

Dalam pengujian univariate, studi ini menginvestigasi abnormal return yang terjadi seputar tanggal pengumuman opini audit. Periode abnormal return dihitung bedasarkan 10 hari tanggal penerbitan laporan keuangan auditan dan 10 hari sebelum diterbitkannya laporan keuangan auditan di Bursa Efek Indonesia. Dalam pengujian ini menggunkan uji Paired sample t-Test untuk nilai residual atau angka error term dari abnormal returns sebelum mendapatkan opini going concern, abnormal returns setelah mendapatkan opini going concern, abnormal returns opini unqualified dan abnormal returns opini going concern.apakah berbeda dengan nol. Opini audit going concern secara statistik terbukti memberikan tambahan informasi kepada pemakai dalam pengambilan keputusan manakala uji ini tidak signifikan atau nilai residual tidak sama dengan nol.

Pengujian ini ditentukan berdasarkan uji rata-rata dan nilai signifikansi dari abnormal returns sebelum mendapatkan opini going concern, abnormal returns setelah mendapatkan opini going concern, abnormal returns opini unqualified dan abnormal returns opini going concern. Nilai rata-rata abnormal returns sebelum mendapatkan opini going concern, abnormal returns setelah mendapatkan opini going concern, abnormal returns opini unqualified dan abnormal returns opini going concern diperoleh dari statistik deskriptif seluruh sampel dan kemudian dilakukan pengujian tingkat signifikansi menggunakan uji Paired sample $t$-Test dengan pengujian hipotesis 2 arah (two tail), yaitu menguji apakah suatu nilai tertentu (yang diberikan sebagai pembanding) berbeda secara nyata ataukah tidak dengan rata-rata sebuah sampel.

Tabel 1

Tabel Perbandingan Returns Sebelum Penerbitan Opini Going Concern dan Sesudah Penerbitan Opini Going Concern

\begin{tabular}{|c|c|c|c|c|c|c|c|c|c|}
\hline \multirow{2}{*}{$\begin{array}{c}\text { Return } \\
\text { sebelum } \\
\text { opini }\end{array}$} & \multicolumn{2}{|c|}{$\begin{array}{c}\text { Sebelum Opini going } \\
\text { Concern }\end{array}$} & \multirow{2}{*}{$\begin{array}{c}\text { Return } \\
\text { sesudah } \\
\text { opini }\end{array}$} & \multicolumn{2}{|c|}{$\begin{array}{c}\text { Sesudah Opini going } \\
\text { Concern }\end{array}$} & \multicolumn{2}{|c|}{ Uji Beda } & \multirow{2}{*}{$\begin{array}{c}\mathbf{T} \\
\text { Value }\end{array}$} & \multirow{2}{*}{$\begin{array}{c}P \\
\text { Value }\end{array}$} \\
\hline & Mean & STD Dev & & Mean & STD Dev & Mean & STD Dev & & \\
\hline-1 &,- 003940 & 0165584 & 1 &,- 000596 & 0244306 & 0033436 & 0318307 & ,779 & ,439 \\
\hline-2 &,- 002018 & ,0432925 & 2 &,- 004489 & 0307417 &,- 0024709 & ,0501936 &,- 365 & ,716 \\
\hline-3 &,- 001058 & ,0254237 & 3 &,- 003091 & ,0164240 &,- 0020327 & ,0316875 &,- 476 & ,636 \\
\hline-4 &,- 001375 & ,0211656 & 4 &,- 003495 & 0174737 &,- 0021200 & ,0286678 &,- 548 & ,586 \\
\hline-5 & ,001035 & 0230455 & 5 & ,004842 & ,0380322 & 0038073 & ,0431012 & ,655 & ,515 \\
\hline-6 &, 003738 & 0324065 & 6 &, 005671 &, 0224786 & ,0019327 & 0438737 &, 327 &, 745 \\
\hline-7 & ,000520 & ,0324203 & 7 & ,000095 & ,0218444 &,- 0004255 & 0382172 &,- 083 & ,935 \\
\hline-8 &,- 000618 & ,0405412 & 8 &,- 000873 & ,0147249 &,- 0002545 & ,0418779 &,- 045 & ,964 \\
\hline-9 &, 000064 & ,0422730 & 9 &, 001176 & ,0217549 & 0011127 &, 0506665 &, 163 &, 871 \\
\hline-10 &,- 000958 & 0194095 & 10 &,- 000609 & 0246026 & 0003491 & 0258401 &, 100 & ,921 \\
\hline
\end{tabular}


Hasil pengujian menunjukkan bahwa nilai $\mathrm{P}$ value rata-rata lebih besar dari $5 \%$ yang artinya bahwa hampir tidak ada perbedaan antara abnormal returns sebelum diterbitkan opini going concern dengan sesudah diterbitkannya opini going concern.

Hal ini selaras dengan penelitian sebelumnya yang dilakukan oleh Richard J. Taffler dan Christine E.L. Tan (2006) dalam penelitiannya terhadap perusahaan di inggris yang menurutnya beranggapan bahwa opini audit going concern tidak berisi informasi baru yang ada di pasar Modal. Sehingga tidak ada perubahan abnormal returns yang begitu signifikan sebelum opini audit going concern diterbitkan dan sesudah opini audit going concern diterbitkan di pasar Modal.

\section{Tabel 2}

\section{Tabel Returns Seputar tanggal Pengumuman Opini Audit (A)}

\begin{tabular}{|c|c|c|c|c|c|c|c|c|}
\hline \multirow{2}{*}{$\begin{array}{c}\text { Return } \\
\text { /Hari }\end{array}$} & \multicolumn{2}{|c|}{ Opini Going Concern } & \multicolumn{2}{|c|}{ Opini Unqualifie } & \multicolumn{2}{|c|}{ Uji Beda } & \multirow{2}{*}{ T Value } & \multirow{2}{*}{ P Value } \\
\hline & Mean & STD Dev & Mean & STD Dev & Mean & STD Dev & & \\
\hline-10 &, 000018 & 0196658 &,- 008121 & ,0249721 &,- 0081385 & 0317091 & $-1,833$ & ,073 \\
\hline-9 &, 000786 & ,0436411 &, 000958 & ,0284215 &, 0001727 & ,0503398 & ,025 & ,981 \\
\hline-8 &,- 001295 & ,0417969 &,- 002780 &, 0244378 &,- 0014846 &, 0493460 &,- 215 & ,831 \\
\hline-7 & ,001347 & ,0311141 &, 001871 & ,0349161 & ,0005243 & ,0435656 & ,086 & ,932 \\
\hline-6 & ,000259 &, 0242433 &, 003305 &, 0322425 &, 0030453 & 0421802 & ,516 & 608 \\
\hline-5 &, 001956 &, 0201824 &,- 008137 & ,0334642 &,- 0100922 & 0381598 & $-1,889$ &, 065 \\
\hline-4 &,- 000977 &, 0219155 &,- 001332 &, 0221064 &,- 0003554 & ,0289044 &,- 088 & ,930 \\
\hline-3 &,- 000857 &, 0254452 &, 000407 & ,0250909 &, 0012634 &, 0352153 & ,256 & ,799 \\
\hline-2 &,- 000484 &, 0434993 &, 000875 & ,0204991 & 0013592 &, 0502715 &, 193 &, 848 \\
\hline-1 &,- 005084 &, 0161683 &, 000068 &, 0181275 &, 0051520 &, 0265939 & 1,383 &, 173 \\
\hline 0 &,- 009659 & ,0200927 &,- 000509 &, 0247605 & ,0091497 & 0322670 & 2,025 & ,048 \\
\hline 1 &, 000293 &, 0250431 &,- 002904 &, 0219634 &,- 0031964 & 0317834 &,- 718 &, 476 \\
\hline 2 &,- 001251 &, 0257278 &,- 006396 & ,0345252 &,- 0051451 &, 0421071 &,- 873 & ,387 \\
\hline 3 &,- 003011 &, 0146456 &,- 004713 &, 0257051 &,- 0017015 & ,0334299 &,- 363 & ,718 \\
\hline 4 &,- 004372 & ,0168902 &,- 003278 &, 0172581 & ,0010945 & ,0264193 & ,296 & ,769 \\
\hline 5 &, 002328 & ,0332948 &, 004561 & ,0361307 & ,0022326 & ,0510337 & ,312 & ,756 \\
\hline 6 &, 005803 &, 0223639 &,- 009798 & ,0355099 &,- 0156015 &, 0430980 & $-2,585$ &, 013 \\
\hline 7 &, 000212 & ,0219168 &, 001843 & ,0222031 & ,0016310 & 0328983 & ,354 & ,725 \\
\hline 8 &,- 000889 & ,0143092 &, 005903 & ,0340418 & ,0067914 & ,0383826 & 1,264 & ,212 \\
\hline 9 &, 001651 & ,0205691 & ,001890 & ,0178002 & ,0002395 & ,0215644 & ,079 & ,937 \\
\hline 10 &, 001378 &, 0221567 &, 007081 &, 0378360 &, 0057030 &, 0423913 & ,961 & ,341 \\
\hline
\end{tabular}

Hasil pengujian menunjukkan nilai $\mathrm{P}$ Value $<5 \%$ pada hari diterbitkannya laporan keuangan auditan di Bursa Efek Indonesia setelah itu pada hari-hari berikutnya baik sebelum diterbitkannya laporan keuangan auditan maupun sesudah diterbitkannya laporan keuangan auditan menunjukkan bahwa tidak terdapat beda nyata antara opini audit going concern dengan opini audit unqualified karena hasil pengujian menunjukkan nilai rata-rata $\mathrm{P}$ Value $>5 \%$. atas hasil tersebut menyatakan bahwa pasar merespon opini audit going concern hanya pada saat diterbitkannya laporan keuangan auditan tersebut di Bursa Efek Indonesia.

Tabel 3

Tabel Returns Seputar tanggal Pengumuman Opini Audit (B)

\begin{tabular}{|c|c|c|c|c|c|c|c|c|}
\hline \multirow[b]{2}{*}{ Return /Hari } & \multicolumn{2}{|c|}{ Opini Goning Concern } & \multicolumn{2}{|c|}{ Opini Unqualifie } & \multicolumn{2}{|c|}{ Uji Beda } & \multirow[b]{2}{*}{ T Value } & \multirow[b]{2}{*}{ P Value } \\
\hline & Mean & STD Dev & Mean & $\begin{array}{l}\text { STD } \\
\text { Dev }\end{array}$ & Mean & $\begin{array}{l}\text { STD } \\
\text { Dev }\end{array}$ & & \\
\hline CAR 10-(10) &,- 013922 &, 0576915 &,- 019020 & ,0818109 &,- 0050980 & , 1023010 &,- 356 & ,723 \\
\hline CAR 5-(5) &,- 019412 & ,0624952 &,- 021176 & ,0582974 &,- 0017647 & ,0829387 &,- 152 & 880 \\
\hline CAR 1-(1) &,- 013137 &, 0295628 &,- 003529 & ,0248856 & ,0096078 & ,0383646 & 1,788 & ,080 \\
\hline
\end{tabular}

Hasil pengujian secara cumulative menunjukkan nilai rata-rata $\mathrm{P}$ Value $>5 \%$ yang menunjukkan bahwa Hipotesis nol di terima daripada hipotesis alternatif yang 
ISSN 1411-0830

berarti bahwa hampir tidak ada perbedaan abnormal return saham antara opini audit going concern dengan opini unqualified.

\section{Pengujian Multivariat}

Pengujian multivariate menggunakan analisis regresi berganda (multiple regression) dengan alasan bahwa variabel independennya lebih dari satu variabel.

Analisis ini digunakan untuk menentukan hubungan antara kumulatif abnormal return dengan variabel-variabel independennya. Persamaan regresinya dirumuskan sebagai berikut :

$\mathrm{CAR}=\alpha+\alpha_{1} \mathrm{GC}+\alpha_{2} \mathrm{MBV}+\alpha_{3} \mathrm{PROF}+$ $\alpha_{4}$ SIZE $+\varepsilon$

Keterangan:
CAR = kumulasi dari abnormal return yang dihitung bedasarkan 10 hari tanggal penerbitan laporan keuangan auditan dan 10 hari sebelum diterbitkannya laporan keuangan auditan di Bursa Efek Indonesia.

$\mathrm{GC}=1$ jika laporan keuangan auditan mendapatkan opini going concern dan nilai 0 jika perusahaan mendapatakan opini unqualified

MBV = rasio pasar terhadap nilai buku dari total ekuitas pada tahun observasi

$\mathrm{PROF}=$ rasio Return on Equity pada tahun observasi

SIZE = nilai logaritma dari total asset pada tahun observasi

$\varepsilon \quad=$ Error

Tabel 4

Descriptive Statistics

\begin{tabular}{|l|r|r|r|r|r|}
\hline & $\mathrm{N}$ & Minimum & Maximum & \multicolumn{1}{l|}{ Mean } & Std. Deviation \\
\hline Opini (X1) & 106 &, 00 & 1,00 &, 5189 &, 50202 \\
MBV (X2) & 106 & $-5,65$ & 41,60 & 3,3213 & 7,83132 \\
ROE (X3) & 106 & $-4,74$ & 3,25 &, 0142 &, 99585 \\
Total Aset (X4) & 106 & 8,83 & 17,40 & 13,8194 & 1,80493 \\
CAR 10 (Y) & 106 &,- 15 &, 23 &,- 0157 &, 07441 \\
CAR 5 (Y) & 106 &,- 18 &, 16 &,- 0211 &, 06043 \\
CAR 1 (Y) & 106 &,- 10 &, 12 &,- 0073 &, 02991 \\
Valid N (listwise) & 106 & & & & \\
\hline
\end{tabular}

Berdasarkan tabel diatas daat dilihat nilai rata-rata dari variabel CAR 10 (Y) adalah sebesar -,0157 dengan nilai standard deviasi sebesar ,07441. Nilai rata-rata dari variabel CAR $5(\mathrm{Y})$ adalah sebesar -,0211 dengan nilai standard deviasi sebesar ,06043. Nilai rata-rata dari variabel CAR 1 (Y) adalah sebesar -,0073 dengan nilai standard deviasi sebesar ,02991. Nilai rata-rata dari variabel OPINI (X1) adalah sebesar ,5189 dengan nilai standard deviasi sebesar ,50202. Nilai rata-rata dari variabel MBV (X2) adalah sebesar 3,3213 dengan nilai standard deviasi sebesar 7,83132. Nilai rata-rata dari variabel ROE (X3) adalah sebesar ,0142 dengan nilai standard deviasi sebesar ,99585. Nilai ratarata dari variabel ASET (X4) adalah sebesar 13,8194 dengan nilai standard deviasi sebesar 1,80493 . 
Aji Prasetyo, Study Respon Investor Terhadap Opini Going Concern...

TABEL 5

Hasil Regresi

Model 1: CAR 10 hari sebelum penerbitan dan 10 hari setelah penerbitan

\begin{tabular}{|c|c|c|c|c|c|c|}
\hline & $\alpha$ & $\mathrm{X} 1$ & $\mathrm{X} 2$ & $\mathbf{X 3}$ & $\mathrm{X} 4$ & \\
\hline \multirow{5}{*}{$\begin{array}{l}\text { Koefisien } \\
\text { t-value } \\
\text { p-value }\end{array}$} & & $-0,25$ & 0.07 & $-0,002$ & $-0,11$ & 0,001 \\
\hline & & $-0,424$ & 0,456 & $-1,761$ & $-1,518$ & 0,200 \\
\hline & & 0,672 & 0,649 & 0,081 & 0,132 & 0,842 \\
\hline & & f-value & & 0,284 & & \\
\hline & & adjs.R2 & & $\mathbf{0 , 0 1 0}$ & & \\
\hline
\end{tabular}

Model 2: CAR 5 hari sebelum penerbitan dan 5 hari setelah penerbitan

\begin{tabular}{lllllll}
\hline & $\alpha$ & X1 & X2 & X3 & X4 & \\
\hline Koefisien & $\mathbf{- 0 , 8 6}$ & $\mathbf{0 , 0 0 3}$ & $\mathbf{0 , 0 0 0 3 9}$ & $\mathbf{0 , 0 0 1}$ & $\mathbf{0 , 0 0 5}$ \\
t-value & $-\mathbf{1 , 7 9 1}$ & $\mathbf{0 , 2 7 4}$ & $\mathbf{0 , 6 0 5}$ & $\mathbf{0 , 9 3 3}$ & $\mathbf{0 , 1 6 6}$ \\
p-value & $\mathbf{0 , 0 7 6}$ & $\mathbf{0 , 7 8 5}$ & $\mathbf{0 , 6 0 5}$ & $\mathbf{0 , 9 3 3}$ & $\mathbf{0 , 1 6 6}$ \\
& f-value & & $\mathbf{0 , 7 0 2}$ & & \\
& adjs.R2 & & $\mathbf{- 0 , 0 1 8}$ & & \\
\hline
\end{tabular}

Model 3: CAR 1 hari sebelum penerbitan dan 1 hari setelah penerbitan

\begin{tabular}{lllllll}
\hline & $\alpha$ & X1 & X2 & X3 & X4 & \\
\hline Koefisien & & $-\mathbf{0 , 0 2 1}$ & $\mathbf{- 0 , 0 0 6}$ & $\mathbf{- 9 , 1 1 5 E - 0 0 5}$ & $\mathbf{0 , 0 0 0 1 2}$ & $\mathbf{0 , 0 0 1}$ \\
t-value & $\mathbf{- 0 , 8 6 8}$ & $\mathbf{- 1 , 0 7 1}$ & $\mathbf{- 0 , 2 4 1}$ & $\mathbf{- 0 , 0 4 2}$ & $\mathbf{0 , 7 4 2}$ \\
p-value & $\mathbf{0 , 3 8 7}$ & $\mathbf{0 , 2 8 7}$ & $\mathbf{0 , 8 1 0}$ & $\mathbf{0 , 9 6 6}$ & $\mathbf{0 , 4 6 0}$ \\
& f-value & & $\mathbf{0 , 7 1 8}$ & & \\
& adjs.R2 & & $\mathbf{- 0 , 0 1 8}$ & & \\
\hline
\end{tabular}

Berdasarkan uji f, hasil pengujian menunjukkan nilai signifikansi untuk uji $\mathrm{F}$ yaitu sebesar $0,284,0,702$ dan 0,718 yang bernilai lebih besar dari 5\%, sehingga dapat disimpulkan bahwa tidak terdapat pengaruh antara OPINI $\left(\mathrm{X}_{1}\right), \mathrm{MBV}\left(\mathrm{X}_{2}\right), \operatorname{ROE}\left(\mathrm{X}_{3}\right)$ dan $\operatorname{ASET}\left(\mathrm{X}_{4}\right)$ terhadap CAR $(\mathrm{Y})$.

Berdasarkan Uji $\mathrm{T}$ nilai p-value masing-masing dari ketiga model diatas menunjukan nilai signifikansi yang bernilai lebih besar dari $\alpha=0.05$, oleh karena itu keputusan adalah tidak tolak $\mathrm{H}_{0}$. Sehingga dapat disimpulkan bahwa tidak terdapat pengaruh antara OPINI $\left(\mathrm{X}_{1}\right), \mathrm{MBV}\left(\mathrm{X}_{2}\right), \mathrm{ROE}$ $\left(\mathrm{X}_{3}\right)$ dan ASET $\left(\mathrm{X}_{4}\right)$ terhadap CAR $(\mathrm{Y})$.

Nilai adj. R2 sebesar -0,018 karena bernilai negative sehingga Adj. R2 dianggap bernilai $0 \%$ - $1 \%$ yang biasanya kurang dari $10 \%$ dan umumnya berda antar $1 \%$ dan $5 \%$ dalam sebagian besar study.

Temuan dalam pengujian regresi ini memberikan bukti bahwa pasar tidak merespon opini audit going concern, karena opini audit pada tahun penelitian tidak menggambarkan informasi yang baru yang ada di pasar modal, sehingga tidak terlihat adanya perubahan harga saham yang signifikan yang mempengaruhi investor dalam mengambil keputusan dan kemungkinan investor hanya memikirkan jumlah dividen yang akan didapatkan dibandingkan melihat pengaruh dari diterbitkannya opini audit.

\section{SIMPULAN, IMPLIKASI DAN SARAN}

\section{Simpulan}

Dalam pengujian hipotesis menggunakan uji beda untuk hipotesis alternative 1 dan hipotesis alternative 2 sedangkan untuk hipotesis alternative 3 peneliti menggunakan regresi berganda yang menghasilkan bukti sebagai berikut: 
1. Tidak terdapat perbedaan antara abnormal return sebelum diterbitkan opini audit going concern dengan setelah menerima opini audit going concern.

2. Tidak terdapat perbedaan abnormal return antara emiten yang memperoleh opini going concern dengan yang memperoleh opini unqualified.

3. Tidak ada pengaruh signifikan opini going concern terhadap cumulative abnormal return.

\section{Implikasi}

Bagi regulator, otoritas pasar modal, investor dan manajemen penelitian ini mempunyai implikasi cukup penting. Otoritas pasar modal, manajemen dan investor sangat berkepentingan untuk bisa mempengaruhi tingkat abnormal return, salah satunya dengan menerbitkan opini audit. Opini audit merupakan sebagian kecil dari faktor- faktor yang mempengaruhi abnormal return dan merupakan salah satu indicator dalam memprediksi kebangkrutan suatu perusahaan.

Seharusnya para stake holder lebih merespon atas diterbitkannya opini audit going concern. Karena opini tersebut dapat secara langsung menggambarkan keadaan suatu perusahaan dan kelangsungan usahanya. Tetapi dalam hal ini investor kurang merespon dengan diterbitkannya opini audit going concern. Opini auditor baik going concern maupun unqualified dianggap sama saja, karena tidak memberikan sebuah informasi yang baru dan biasanya pada saat akhir tahun perusahaan lebih melakukan window dressing, sebagai hasilnya return saham perusahaan hampir tidak ada perubahan.

\section{Saran}

Ada beberapa saran yang bisa diajukan yang terkait dengan hasil penelitian ini bagi penelitian-penelitian selanjutnya.

1. Peneliti bisa menggunakan variable control yang lain yang dapat diujikan dalam penelitian selanjutnya seperti kinerja, leverage dsb.
2. Data observasi bisa lebih di perbanyak jumlahnya dan periode yang di teliti di perpanjang. Karena semakin sedikitnya perusahaan yang mendapatkan opini going concern.

3. Peneliti bisa membuat model cumulative abnormal return yang lain seperti 2 hari sebelum sampai 2 hari sesudah diterbitkan laporan keuangan auditan.

\section{DAFTAR PUSTAKA}

Biro Riset Ekonomi Direktorat Riset Ekonomi dan Kebijakan Moneter, Bank Indonesia (2009), "Outlook Ekonomi Indonesia: Krisis Finansial Global dan Dampaknya terhadap Perekonomian Indonesia".

Bursa Efek Jakarta (2011), "Indonesian Capital Market Directory", Institute For Economic And Financial Research.

(2012), "Indonesian

Capital Market Directory", Institute For Economic And Financial Research.

(2013), "Indonesian

Capital Market Directory”, Institute For Economic And Financial Research.

Diah Kusuma Wardhani. (2008), "Pengaruh Corporate Governance Terhadap Kinerja Perusahaan di Indonesia", Skripsi, Universitas Islam Indonesia.

Edy Rismanda Sembiring. (2005), "Karakteristik Perusahaan dan Pengungkapan Tanggung Jawab Sosial: Studi Empiris pada Perusahaan yang Tercatat di BEJ", Simposium Nasional Akuntansi VIII.

Eugene F. Brigham dan Joel F. Houston (2009), Essentials of Financial Management, Edisi ke 2, Singapura: Cengage Learning Asia Pte Ltd.

Fama, Eugene F. (1992), "Efficient Market: A Review of Theory and Empirical Work", Journal of Finance, 25 (2):383417. (1992), "The Cross-Section of Expected 
Aji Prasetyo, Study Respon Investor Terhadap Opini Going Concern...

Stock Returns." The Journal o f Finance 47, no. 2: 427-465.Journal of Finance 47, no. 2: 427-465.

Firth, Michael (1978), "Qualified Audit Reports: Their Impact on Investment Decisions." The Accounting Review 53, no. 3: 642-650.

Hani, Clearly, dan Mukhlasin (2003), “Going Concern dan Opini Audit: Suatu Studi pada Perusahaan Perbankan di BEJ", Simposium Nasional Akuntansi VI.

Horne, James C. V. and Wachoviz Jr, John M. (2008), "Fundamental of Financial Management 13th ed", New Jersey: Prentice Hall International.

Ikatan Akuntan Indonesia (2012), "Standar Akuntansi Keuangan Per 1 Juni 2012”, Jakarta: Ikatan Akuntan Indonesia.

Institut Akuntan Publik Indonesia (2011), "Standar Profesional Akuntan Publik", Jakarta: Salemba Empat.

Jogiyanto H. M, (2000), "Teori Portofolio dan Analisis Investasi", Edisi 3, BPFE UGM, Yogyakarta.

------------, (2003), “Teori Portofolio dan Analisis Investasi”, Edisi Ketiga, Yogyakarta: BPFE, Yogyakarta. , (2009), "Teori Portofolio dan Analisis Investasi”, Yogyakarta: BPFE, Yogyakarta.

Kevin C. W. Chen dan Bryan K. Church (1992), "Default on Debt Obligations and The Issuance of Going-Concern Report", Auditing: Journal Practice and Theory, Fall, 30-49.

(1996), "Going Concern Opinions and the Market's Reaction to Bankruptcy Filings", The Accounting Review, 117128.

Lianny Leo (2007), “Incremental Information Content dalam Opini Audit Unqualified dengan Paragraf Penjelasan, Jurnal Akuntansi dan Keuangan Indonesia, Vol.4, No.2, hal.115-168.

Marisi P. Purba (2009)," Asumsi Going Concern Suatu Tinjauan Terhadap Dampak Krisis Keuangan atas Opini Audit dan Laporan Keuangan", Yogyakarta: Graha Ilmu.

Michael C. Jensen dan William H. Meckling (1976), "Theory of the Firm: Managerial Behavior, Agency Costs and Ownership Structure", Journal of Financial Economics, Vol. 3, No. 4.

Putu Terestiani Dadri (2011), "Pengaruh Investment Opportunity Set dan Struktur Modal terhadap Return Saham Pada Perusahaan Farmasi di Bursa Efek Indonesia", Tesis, Universitas Udayana.

Richard J. Taffler and Christine E.L.Tan (2006), "The Impact of Bankruptcy on the Value of the Auditor's Going Concern Opinion to Investors", CAAA 2006 Annual Conference Paper.

Thio Anastasia Petronela (2004), "Pertimbangan Going Concern Perusahaan Dalam Pemberian Opini Audit", Jurnal Balance, 45-54.

William F. Messier, Jr, Steven M. Glover, dan Douglas F. Prawitt (2006), "Auditing and Assurance Services a Systematic Approach, Jasa Audit \& Assurance Pendekatan Sistematis", Edisi 4 Indonesia Buku Satu, Jakarta: Salemba Empat.

Yulius Kurnia Susanto (2009), "FaktorFaktor yang Mempengaruhi Penerimaan Opini Audit Going Concern pada Perusahaan Publik Sektor Manufaktur", Jurnal Bisnis Dan Akuntansi Vol. 11, No. 3, 155-173. 